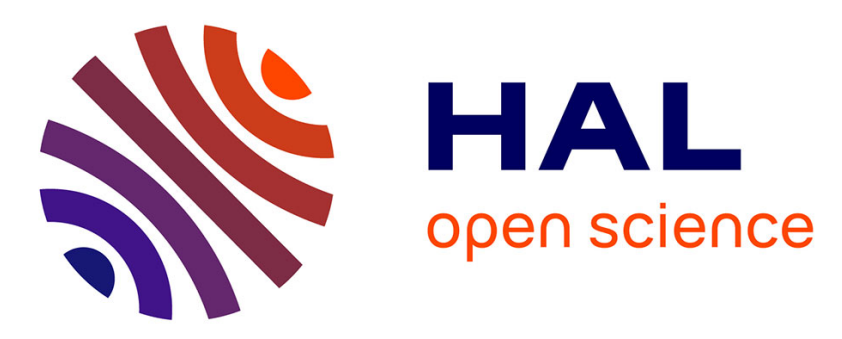

\title{
Recent advances in bivalve-microbiota interactions for disease prevention in aquaculture
}

Christine Paillard, Yannick Gueguen, K Mathias Wegner, David Bass, Alberto Pallavicini, Luigi Vezzulli, Isabelle Arzul

\section{- To cite this version:}

Christine Paillard, Yannick Gueguen, K Mathias Wegner, David Bass, Alberto Pallavicini, et al.. Recent advances in bivalve-microbiota interactions for disease prevention in aquaculture. Current Opinion in Biotechnology, 2022, 73, pp.225-232. 10.1016/j.copbio.2021.07.026 . hal-03355019

\section{HAL Id: hal-03355019 https://hal.science/hal-03355019}

Submitted on 27 Sep 2021

HAL is a multi-disciplinary open access archive for the deposit and dissemination of scientific research documents, whether they are published or not. The documents may come from teaching and research institutions in France or abroad, or from public or private research centers.
L'archive ouverte pluridisciplinaire HAL, est destinée au dépôt et à la diffusion de documents scientifiques de niveau recherche, publiés ou non, émanant des établissements d'enseignement et de recherche français ou étrangers, des laboratoires publics ou privés. 


\title{
Recent advances in bivalve-microbiota interactions for disease prevention in aquaculture
}

\author{
Christine Paillard ${ }^{1,11}$, Yannick Gueguen ${ }^{2,11}$, K Mathias Wegner ${ }^{3}$, \\ David Bass ${ }^{4,5,6}$, Alberto Pallavicini ${ }^{7,8}$, Luigi Vezzulli ${ }^{9}$ and Isabelle Arzul ${ }^{10}$
}

1 Univ Brest, CNRS, IRD, Ifremer, LEMAR, F-29280 Plouzané , France 2 IHPE, Univ Montpellier, CNRS, Ifremer, UPVD, Montpellier, France 3Alfred Wegener Institute - Helmholtz Centre for Polar and Marine Research, Coastal Ecology, Waddensea Station Sylt, D-25992 List, Germany

4 International Centre of Excellence for Aquatic Animal Health, Centre for Environment Fisheries and Aquaculture Science (Cefas), Weymouth Laboratory, Weymouth, DT4 8UB Dorset, UK

5 Centre for Sustainable Aquaculture Futures, University of Exeter, College of Life and Environmental Sciences, University of Exeter, EX4 4QD Exeter, UK

6 Department of Life Sciences, The Natural History Museum, Cromwell Road, SW7 5BD London, UK

7 Department of Life Sciences, University of Trieste, Via Licio Giorgeri 5, 34126 Trieste, Italy

8 National Institute of Oceanography and Applied Geophysics, via Piccard 54, 34151 Trieste, Italy

9 Department of Earth, Environmental and Life Sciences (DISTAV), University of Genoa, Corso Europa 26, 16132

Genoa, Italy

10 Ifremer, RBE-SG2M-LGPMM, Station de La Tremblade, Avenue de Mus de Loup, F-17390 La Tremblade, France 11 These authors contributed equally.

Corresponding authors:

Paillard, Christine (christine.paillard@univ-brest.fr),

Gueguen, Yannick (ygueguen@ifremer.fr),

Arzul, Isabelle (isabelle.arzul@ifremer.fr)

\section{ABSTRACT}

In bivalves, no clear-cut functional role of microbiota has yet been identified, although many publications suggest that they could be involved in nutrition or immunity of their host. In the context of climate change, integrative approaches at the crossroads of disciplines have been developed to explore the environment-host-pathogen microbiota system. Here, we attempt to synthesize work on (1) the current methodologies to analyse bivalve microbiota, (2) the comparison of microbiota between species, between host compartments and their surrounding habitat, (3) how the bivalve microbiota are governed by environmental factors and host genetics and (4) how host-associated microorganisms act as a buffer against pathogens and/or promote recovery, and could thereby play a role in the prevention of disease or mortalities. 


\section{Introduction}

Marine bivalves are ecological keystone species that fulfill essential roles in coastal ecosystems by providing habitat, mediating bentho-pelagic energy fluxes, and maintaining water quality. Their benthic filter-feeding lifestyle also makes them useful sentinels to detect pollution [1**]. Bivalves are also economically highly important aquaculture species, with a world aquaculture production of molluscs for human consumption reaching 17.5 million tons in 2018 [2]. Aquaculture production and natural populations are strongly impacted by environmental fluctuations of biotic and abiotic factors. In recent years, infectious diseases have emerged as the major limiting factors for bivalve production, but very few tools are available to prevent and treat infections [3*]. Techniques developed for the production of other ani mals cannot be directly applied to bivalve aquaculture, since the lack of antibody-mediated immune memory prevents individual vaccination approaches, and culture in the open sea prevents application of large-scale disease treatments.

In marine ecosystems, including open sea aquaculture, bivalves are exposed and colonized by a plethora of microorganisms [1**] making host-microorganisms interactions a prime target for understanding bivalve health [3*,4-6]. Microorganisms can fulfill beneficial functions for the host and vice versa, and the holobiont concept captures these relationships by merging hosts and their associated microbiota into a single evolutionary unit of selection [7]. It suggests that microbiota composition provides benefits to the hosts for survival, but also homeostasis and development. For example, studies of resident microorganisms in the haemolymph of healthy bivalves suggest that the host-microbiome could limit settlement of pathogenic strains and play a role in preventing dysbiosis and aiding health recovery $\left[8^{* *}, 9\right]$.

Facilitated by the advances in high-throughput sequencing technologies, interactions between host immune responses and their associated microbiota are increasingly investigated within the context of disease [10]. Here, we review not only the methodologies used to characterize bivalve microbiota, but also the factors that structure microbiomes associated with bivalves under aquaculture conditions and highlight 1 ) their composition and host specificity, 2) interactions between environment and host-associated microbiomes, and 3 ) how these interactions may affect the ability of bivalves to resist pathogens. This review highlights critical gaps in our understanding of microbiome function, and identifies research priorities leading to innovative management practices of molluscan aquaculture in the future.

\section{Current methodologies}

Typically, microbial communities associated with bivalves of aquaculture interest have been taxonomically characterized and analysed by massive amplicon sequencing of genes encoding small subunit ribosomal RNA gene regions (Figure 1) $\left[1^{* *}, 11^{*}, 12^{* *}, 13^{*}\right]$. While microbiota are often characterized by $16 \mathrm{~S}$ sequencing of bacteria, the eukaryotic genetic diversity is rarely investigated $\left[14,15^{* *}\right]$. A more comprehensive approach than ribosomal amplicon sequencing is shotgun metagenomics, which offers the advantage to target the whole microbial gene pool within a sample with the possibility to run functional analysis as well as assembling genomes. Shotgun metagenome analysis applied to the study of Pacific oyster microbiome recently revealed that oyster hemolymph is a complex ecosystem containing diverse bacteria, protists and viruses [15**]. However, the bioinformatic processing of metagenome data is not yet standardized and the application ofshotgun metagenomicsfor the analysis of the bivalve microbiota is still challenging [15**].

An important limitation of metagenomic or eukaryotic metabarcoding studies is co-sequencing of host DNA that largely masks target DNA from host-associated microbial communities [16]. Ultradeep sequencing or target sequencing implying removal of non-target DNA from samples before sequencing significantly overcomes this problem. In particular, hybridization-based capture with target-specific biotinylated probes is a versatile and cost effective technique for the sequencing of both 
viruses and bacteria in complex samples [17]. Vezzulli et al. [18] demonstrates that by using such an approach, ultra-low abundance Vibrio cholerae genomes, including specific virulence factors, could be retrieved from raw river water approximately 2500 times more effectively than shotgun sequencing alone. By applying the same methodology, 884 phylogenetic and virulence markers of the potential microbial pathogenic community were targeted in oyster tissue allowing high taxonomic resolution analysis of the bivalve pathobiota [19*]. For studying host-associated micro-eukaryotes, metabarcoding primers are available that reduce co-amplification of metazoan host sequences, enabling more thorough sequencing of micro-eukaryotic symbionts and parasites $[14,20]$.

DNA sequencing technologies are rapidly evolving and are expected to contribute to new breakthroughs in the study of the bivalve microbiota. Latest technologies such as long-read targeted sequencing [21] or new ultra-deep sequencing platforms (e.g. NovaSeq 6000) are certainly paving the way to a more comprehensive analysis and understanding of the bivalve holobiont.

\section{Host factors shaping bivalve microbiota}

The structure of bivalve-microbiota interactions is clearly stratified by host factors on different scales nested within each other: species $\left[22^{* *}\right]$, populations within species $\left[15^{* *}, 23\right]$, and individuals/genotypes within populations $\left[8^{* *}, 12^{* *}, 24^{* *}\right]$. Furthermore microbiomes change across developmental stages [25*] and between organs $\left[26,27^{*}\right]$.

Comparative studies have mostly been carried out on oysters and mussels [ex: $\left.12^{* *}, 22^{* *}, 28^{*}, 29\right]$ and to a lesser extent on clams $\left[11^{*}, 13^{*}\right]$. Species collected from similar environments displayed a high degree of similarity and a high number of shared core OTUs [22**,28*], indicating that uptake from environmental strains by suspension feeding is a major determinant of microbiome composition. Yet, bivalve species clearly differ in microbiome composition and relative abundances of taxa, which may partly explain the better capacity of a particular species to defend against pathogens or to survive in specific environmental conditions $\left[18^{* *}, 28^{*}\right]$. Microbiome composition shows stable differences between individuals $\left[8^{* *}\right]$ and these host genotypic background signals can persist over months [23]. Indeed, genetics can partly explain microbiome structure in different oyster species (e.g. Crassostrea gigas, Saccostrea glomerata) [12**,15**,24**].

Genotype associated patterns can however vary within individuals according to developmental stage or tissues [30]. Interestingly, species richness has been shown to decrease as larvae develop suggesting a shift towards a more specific microbiome [25*]. This trend also continued between later stages (postlarvae and adults), with adults showing the lowest diversity [31]. In later developmental stages, tissue type becomes a strong determinant of bacterial community composition [23,32]. In particular, microbiota vary between internal organs such as gut and those that are in closer contact to the environment (e.g. hemolymph or gills). This pattern, consistent across individuals of different species [33], might suggest a role of microbiota in different physiological processes specific to the investigated organ.

On all levels, the effects of host-associated factors on compositional microbiome diversity are strongly influenced by environmental variation. Environmental disturbance for example can homogenize inter-individual differences $\left[8^{* *}\right]$ or deplete genetic signals $\left[24^{* *}\right]$. In many cases, for example, on the population level, environmental and host genetic effects will be confounded, therefore, it is imperative to consider the interaction of host-specific and environmental effects when describing host-microbiota interactions. 


\section{Environmental factors modifying bivalve microbiota}

The influence of environmental factors on bivalve microbiota can be explained by the benthic lifestyle of bivalves and its heterogeneity at small spatial scales (ecological niches, sessile versus freeliving life stages), and by the spatial and temporal variation of abiotic and biotic factors (season, transplantation, pollution, pathogens, water quality, and so on). Microbiota-environment interactions have repeatedly been studied by monitoring bivalves in the field, either over short or long periods. Specific diversity patterns suggest that bivalves select the microorganisms from the water column or sediment, depending on their microbiota compartment. This microbiota selection process is modified with the time of exposure for intertidal bivalves $\left[13^{*}\right]$, but also with the seasons [11**]. The influence of stochastic processes may also be a factor for microbiota diversity [1**]. The transfer of bivalves from hatcheries to rearing sites plays an essential role in shaping the microbiome from juveniles to adults [29].

The initial microbiome (bacteria, protist and virus) is deeply modified by transplantation (strongly for transient microbiome, and lessfor resident microbiota such asthose from digestive gland), according to the environmental conditions of the new rearing sites $\left[12^{* *}, 15^{* *}, 27^{*}, 34^{*}\right]$.

Altogether, results indicate that bivalve microbiota is at least partly originated from the marine microbiota where these organisms are living. Water pollution could also impact bivalve microbiota. Titanium dioxide nanoparticles $\left(\mathrm{nTiO}_{2}\right)$ - very widely used in a diverse range of products - and PS$\mathrm{NH}_{2}$ nanoplastic have been shown to affect the Mytilus galloprovincialis microbiota [35,36]. Similarly, oysters exposed to atrazine, a prevalent herbicide in agricultural practice, result in a significant loss of key mutualistic microbial species and a subsequent colonization of pathogenic bacteria [37]. Exposure to estrogenic chemicals such as $17 \beta$-estradiol, Bisphenol $\mathrm{A}$ and Bisphenol $\mathrm{F}$ is also leading to changes in the microbiota composition of first larval stages of M. galloprovincialis [38].

Water temperature seems to be a major driver and strongly influences the composition of oyster microbiota both in the haemolymph $\left[8^{* *}, 33\right]$ and other tissues $\left[19^{*}\right]$, and only a small fraction of the microbial species persist as a 'core' community throughout the different seasons.

Accordingly, climate change was observed to alter the microbiome of the Sydney rock oyster $S$. glomerata [39]. Warmer temperatures are also favoring the proliferation of potential pathogenic bacteria (e.g. Vibrio) within bivalve microbiota, thus increasing susceptibility to microbial diseases $[40,41]$.

\section{Microbiota and bivalve health}

Microbiota are hypothesized to influence disease susceptibility [1**,7]. However, in bivalves few studies have explicitly described the role of these host-microbial interactions in buffering the host against fluctuating conditions (enantiostasis). In particular, investigations into the roles of microbiota in host health and disease have so far mostly focused on oysters (Crassostrea and Saccostrea species) from a solely bacterial perspective. However, it is clear that the bivalve symbiome also includes viruses and microeukaryotes, the identities and roles of which are only just starting to be investigated [15**].

Oyster bacterial microbiota are dynamic and were shown to be modified in response to multiple stressors, including pathogens $\left[8^{* *}, 15^{* *}, 24^{* *}, 27^{*}, 34^{*}, 42-45\right]$. Recently, [43] demonstrated that Pacific Oyster Mortality Syndrome affecting $C$. gigas oyster throughout the world is associated with a disruption of the host microbiota. This study showed that infection by an Ostreid herpesvirus compromises the oyster antibacterial defence and is followed by a microbiota shift leading to bacteremia and oyster death [43]. Field analysis performed on C. gigas also revealed that oysters experiencing mortality outbreaks at different life stages displayed signs of dysbiosis $[19 *, 46]$. Nevertheless, it is often unclear whether an altered microbiota is a cause or result of the impact of invading pathogen(s). Examples are known of both situations, and it is important to consider both 
options in each case. Experimental investigations and temporal sampling are required to better understand causal relationships [47].

Recent studies highlight the potential involvement of oyster microbiota in disease resistance. They showed that the microbiomes of disease-susceptible oyster families were significantly different from the microbiomes of disease-resistant families [48,49*]. The differences observed suggested that both the structure and the composition of the microbiota might predict oyster mortalities [49*]. Interestingly, the microbiota of oysters originating from the same hatchery picked up genotypespecific signals of their different rearing environment in the field and this was correlated with different outcomesto Ostreid herpesvirus infection [34*]. Bacterial taxa explaining genotype-specific differences offer the opportunity to identify putative microbial determinants of disease resistance. Accordingly, a row of key bacterial taxa were identified, which may provide a protective or detrimental role in disease outbreaks of oysters (Table 1) [45,48,49*].

The diversity and roles of microeukaryotic symbionts are both almost certainly much greater than currently appreciated. It is increasingly recognized that bivalves are host to a diversity of protistan parasites that have an indeterminate effect on the host. Some of these can occur at relatively high prevalence without a clearly discernible effect on the populations (e.g. Minchinia mytili in Mytilus edulis; [50], and another currently undescribed Minchinia species in Cerastoderma edule; [51]). The effects of these parasites may become more apparent under conditions of environmental or other physiological stress on their hosts. Further research is now required to elucidate the dynamic reciprocity between the whole microbiota and host in the context of pathogenesis, and host susceptibility and resistance to disease.

\section{Conclusion}

Over the last few years many studies have investigated the bacterial microbiome of a wide range of bivalves, in both healthy and diseased states (Figure 1). These have shown that the structure and the composition of microbiota is influenced by the ecology and geography of the sampling site, season, host life stage, and health status among other factors (Figure 2). Studies of the microbiomes of farmed bivalves to date have focused on oysters with or without associated mortality events. It will thus be important to complement these with new studies underway on other bivalves affected by chronic diseases including microparasites (e.g. Perkinsosis and Brown R Disease in Manila clams, Juvenile Oyster Disease and Perkinsosis in C. virginica). Integrating the dynamics of the whole symbiota bacteria, viruses, and eukaryotes - and its interaction with the host and surrounding environment, should be the ultimate aim to achieve a comprehensive understanding of bivalve physiological states, including health [47].

Research on microbiome modulator drugs (prebiotics, probiotics, synbiotics) for the health of cultured bivalves should be developed as its value has been demonstrated for other invertebrates such as shrimp [52]. So far, our understanding of bivalve microbiota has focused on its structural aspects, but the large diversity and variability of these microbiota have precluded the identification of probiotic taxa providing protection against disease. Alternative approaches using Bacillus pumilus RI06-95 as a probiotic in oyster hatcheries has shown some evidence of decrease of pathogenic microorganisms [45]. Several studies on bivalves - and also on other invertebrates and vertebrates - suggest that the gut compartment harbors a more stable microbiota, including symbionts, and could be a good lead for the identification of a potential microbiota profile. Manipulation of the gut microbiome could also improve immunity and health of bivalves as has been done for shrimps [52]. Probiotics interact with the immune system and prevent pathogen colonization in multiple ways [53]. They can directly compete with pathogens for the same niche (competition for nutrients or production of antimicrobial molecules) and also stimulate the host immune system. These contributions to bivalve defenses are still poorly understood and could be developed as one of the additional strategies to combat disease 
in bivalve aquaculture. Phage therapy using specific or cocktails of bacteriophages, could be also used to limit pathogen colonization [3*].

Complementary approaches (including various 'omics, microscopy techniques, (epi)genetics, and immunology) integrating microbiome studies with host and environmental factors will allow us to better understand the dynamics of microbiota across a diversity of environments and hosts and should help us to identify, for example through network interaction studies, taxa predictive of survival as well as mortality events $[54,55]$. The more comprehensive understanding that is resulting from these integrated approaches will enable us to better manage bivalve aquaculture, and mitigate problems. Pathobiotic systems can be reversed within certain boundaries, and host health status is a result not just of individual pathogens but a greater diversity of influences, of which we have increasing understanding and ability to manipulate. Collaboration between producers, farm managers, and scientists from diverse disciplines (e.g. microbial ecology, pathology, environmental science, modeling, chemistry, genetics, immunology, and so on) will be key to this success.

\section{Conflict of interest statement}

Nothing declared

\section{Acknowledgements}

This work was supported by the European Project H2020 VIVALDI and has received funding from the European Union $\mathrm{H} 2020$ research and innovation program under grant agreement no. 678589 . It was also supported by ISBLUE project, Interdisciplinary Graduate School for the blue planet (ANR-17EURE-0015) and co-funded by a grant from the French Government under the program 'Investissements d'Avenir'. 


\section{References and recommended reading}

Papers of particular interest, published within the period of review, have been highlighted as:

* of special interest

** of outstanding interest

1** Pierce ML, Ward JE: Microbial ecology of the Bivalvia, with an Emphasis on the Family Ostreidae. J Shellfish Res 2018, 37:793- 806 Pierce et al. reviewed the current knowledge of the spatial and temporal distributions of bivalve-associated microorganisms, microbial functional and genetic diversity, hostspecific and tissue-specific interactions, and core microbial community composition.

2 FAO Yearbook: Fishery and Aquaculture Statistics 2018/FAO Annuaire. Statistiques des Pêches et de I'Aquaculture 2018/FAO Anuario. Rome: Estadisticas de pesca y acuicultura; 2018 http:// dx.doi.org/10.4060/cb1213t.

3* Pérez-Sànchez T, Mora-Sànchez B, Balcàzar JL: Biological approaches for disease control in aquaculture: advantages, limitations and challenges. Trends Microbiol 2018, 26:896-903 Infectious diseases have become a prominent limiting factor for aquaculture. In addition, growing global concerns about antibiotic resistance have prompted the search for environmentally friendly approaches. In this context, PerezSanchez et al. offer an update on the successes and challenges of biological approaches for bacterial disease prevention and control in aquaculture. Examples of biological approaches include the use of probiotics, prebiotics, synbiotics, postbiotics or quorum sensing interference.

4 Dittmann KK, Rasmussen BB, Castex M, Gram L, Bentzon-Tilia M: The aquaculture microbiome at the centre of business creation. Microb Biotechnol 2017, 10:1279-1282.

5 Apprill A: Marine animal microbiomes: toward understanding host-microbiome interactions in a changing ocean. Front Mar Sci 2017, 4 http://dx.doi.org/10.3389/fmars.2017.00222.

6 King WL, Jenkins C, Seymour JR, Labbate M: Oyster disease in a changing environment: decrypting the link between pathogen, microbiome and environment. Mar Environ Res 2019, 143:124140.

7 Rosenberg E, Zilber-Rosenberg I: The hologenome concept of evolution after 10 years. Microbiome 2018, 6:78 http://dx.doi. org/10.1186/s40168-018-0457-9.

8** Lokmer A, Wegner MK: Hemolymph microbiome of Pacific oysters in response to temperature, temperature stress and infection. ISME J 2015, 9:670-682. Lokmer and Wegner used an experimental setup to investigate the interaction of temperature, temperature stress (shifts between temperature treatments) and infection on the composition of the haemolymph microbiome. By repeatedly sampling the same individual they could show that higher temperatures lead to a more dynamic microbiome composition with acclimated animals showing distinct personalized microbiota. Temperature stress homogenized variation between individuals. Bacterial infection mainly reduced the microbiome diversity in sick animals with diseased animals showing reduced diversity giving rise to opportunists that dominating the hemolymph communities. 'Healthy' microbiomes seem to prevent dysbiosis, but environmental factors reduce microbiome stability.

9 Desriac F, Le Chevalier P, Brillet B, Leguerinel I, Thuillier B, Paillard C, Fleury Y: Exploring the hologenome concept in marine bivalvia: haemolymph microbiota as a pertinent source of probiotics for aquaculture. FEMS Microbiol Lett 2014, 350:107-116.

10 Lozupone CA: Unraveling interactions between the microbiome and the host immune system to decipher mechanisms of disease. mSystems 2018, 3:e00183-17 http://dx. doi.org/10.1128/mSystems.00183-17.

11* Neu AT, Hughes IV, Allen EE, Roy K: Decade-scale stability and change in a marine bivalve microbiome. Mol Ecol 2021, 30:1237-1250 Neu et al. quantified the diversity and composition of Donax gouldii microbiome over a decadal timescale. Despite increases in water temperature $\left(+1.6^{\circ} \mathrm{C}\right.$ due to seasonal change) and chlorophyll a concentration (more than ninefold) the diversity of microbial taxa did not change. However this stability was underlain by substantial turnover in the composition of the microbiome, with only six amplicon sequence variants (ASVs) persisting over the sampling period. 
$12 * *$ Nguyen VK, King WL, Siboni N, Mahbub KR, Dove M, O'Connor W, Seymour JR, Labbate M: The Sydney rock oyster microbiota is influenced by location, season and genetics. Aquaculture 2020:735472 http://dx.doi.org/10.1016/j.aquaculture.2020.735472 Nguyen et al. demonstrated that multifactorial factors (environmental and genetic links to disease resistance) act in synergy to shape the microbiota of the benthic bivalves. This study showed the strong impact of the location and season, but also the role of the composition of the microbiota to prevent $Q X$-disease development in Saccrostrea glomerata.

13* Offret C, Paulino S, Gauthier O, Château K, Bidault A, Corporeau C, Miner P, Petton B, Pernet $\mathrm{F}$, Fabioux $\mathrm{C}$ et al.: The marine intertidal zone shapes oyster and clam digestive bacterial microbiota. FEMS Microbiol Ecol 2020, 96 http://dx.doi. org/10.1093/femsec/fiaa078 PMID: 32353873 The digestive gland (DG) microbiota of two bivalves the pacific oyster - Crassostrea gigas and the manila clam Ruditapes philippinarum, is highly influenced by the site of implantation. The structuration of DG microbiota is in accordance with their ecological niche. The intertidal imprint is only observed in the clam DG microbiota (non-depurated and depurated), suggesting the existence of autochthonous bacteria in the clam DG microbiota.

14 Clerissi C, Guillou L, Escoubas J-M, Toulza E: Unveiling protist diversity associated with the Pacific oyster Crassostrea gigas using blocking and excluding primers. BMC Microbiol 2020, 20:193 http://dx.doi.org/10.1186/s12866-020-01860-1.

15** Dupont S, Lokmer A, Corre E, Auguet J-C, Petton B, Toulza E, Montagnani C, Tanguy G, Pecqueur $D$, Salmeron $C$ et al.: Oyster hemolymph is a complex and dynamic ecosystem hosting bacteria, protists and viruses. Anim Microbiome 2020, 2:12 http://dx.doi.org/10.1186/s42523-02000032-w Dupont et al. reared five oyster families differing in susceptibility to the Pacific oyster mortality syndrome in hatchery and transplanted them into a natural environment either before or during a disease outbreak. Using metabarcoding and shotgun metagenomics, they showed that oyster hemolymph is a complex ecosystem containing diverse bacteria, protists and viruses, whose composition and dynamics are primarily determined by the environment. However, all of these are also shaped by oyster genetic backgrounds, indicating they indeed interact with the oyster host and are therefore not only of transient character. Co-occurrence network analyses suggest a disruption of the microbial network after transplantation into natural environment during both non-infectious and infectious periods.

16 Bharti R, Grimm DG: Current challenges and best-practice protocols for microbiome analysis. Brief Bioinform 2021, 22:178-193.

17 Mamanova L, Coffey AJ, Scott CE, Kozarewa I, Turner EH, Kumar A, Howard E, Shendure J, Turner DJ: Target-enrichment strategies for next-generation sequencing. Nat Methods 2010, 7:111118.

18 Vezzulli Luigi et al.: Whole-genome enrichment provides deep insights into vibrio cholerae metagenome from an African river. Microb Ecol 2017, 73:734-738 http://dx.doi.org/10.1007/ s00248016-0902-x.

19* Lasa A, di Cesare A, Tassistro G, Borello A, Gualdi S, Furones D, Carrasco N, Cheslett D, Brechon A, Paillard C, Bidault A: Dynamics of the Pacific oyster pathobiota during mortality episodes in Europe assessed by $16 \mathrm{~S}$ rRNA gene profiling and a new target enrichment next-generation sequencing strategy. Environ Microbiol 2019, 21:4548-4562 In this study comparative analysis of contrasting C. gigas samples collected during recurrent mortality episodes at different European sites was conducted using 165 rRNA metabarcoding and target enrichment metagenomics. This represents, to date, the largest study investigating the structure and dynamics of farmed oysters' microbiota.

20 Bass D, Del Campo J: Micro-eukaryotes in animal and plant microbiomes: ecologies of disease? Eur J Protistol 2020, 76:125719.

21 Kovaka S, Fan Y, Ni B, Timp W, Schatz MC: Targeted nanopore sequencing by real-time mapping of raw electrical signal with UNCALLED. Nat Biotechnol 2021, 39:431-441.

$22^{* *}$ Vezzulli L, Stagnaro L, Grande C, Tassistro G, Canesi L, Pruzzo C: Comparative 16SrDNA gene-based microbiota profiles of the pacific oyster (Crassostrea gigas) and the mediterranean mussel (Mytilus galloprovincialis) from a shellfish farm (Ligurian Sea, Italy). Microb Ecol 2018, 75:495-504 
Vezulli et al., carried out a comparative analysis of haemolymph and digestive gland microbiota in C. gigas and M. galloprovincialis co-cultivated at the same aquaculture site using 16SrDNA pyrosequencing. It was found that Vibrio, including potential pathogenic species, accounted for a larger fraction of the microbiota in C. gigas compared to M. galloprovincialis. In addition, microbiome analyses performed on bivalve specimens subjected to commercial depuration highlighted the ineffectiveness of such practice in removing Vibrio species from bivalve tissues.

23 Lokmer A, Kuenzel S, Baines JF, Wegner KM: The role of tissue specific microbiota in initial establishment success of Pacific oysters. Environ Microbiol 2016, 18:970-987.

$24 * *$ Wegner KM, Volkenborn N, Peter H, Eiler A: Disturbance induced decoupling between host genetics and composition of the associated microbiome. BMC Microbiol 2013, 13:252 http://dx. doi.org/10.1186/1471-2180-13-252 Wegner et al. investigated the microbiome composition of oysters from genetically differentiated beds, and could show that microbiome differentiation correlated to genetic differentiation of the host, suggesting an important role of host genetics on microbiome assembly. This genotypespecific composition was however sensitive to environmental disturbance since the association fell apart after heat shock treatment, highlighting the importance not to consider environmental and genetic effect in isolation.

25* Arfken A, Song B, Allen SK, Carnegie RB: Comparing larval microbiomes of the eastern oyster (Crassostrea virginica) raised in different hatcheries. Aquaculture 2021, $531 \mathrm{http}: / / \mathrm{dx}$. doi.org/10.1016/j.aquaculture.2020.735955 Arfken et al. showed that oyster larval microbiomes were significantly different from water microbiomes with significant influence of hatchery types and spawning seasons. Obtained results highlight the importance of environmental conditions on microbiome development of oyster larvae associated with hatchery success of larval cultivation.

26 King GM, Judd C, Kuske CR, Smith C: Analysis of Stomach and gut microbiomes of the eastern oyster (Crassostrea virginica) from Coastal Louisiana, USA. PLoS One 2012, 7:e51475 http:// dx.doi.org/10.1371/journal.pone.0051475.

27* Lokmer A, Goedknegt MA, Thieltges DW, Fiorentino D, Kuenzel S, Baines JF, Wegner KM: Spatial and temporal dynamics of Pacific oyster Hemolymph microbiota across multiple scales. Front Microbiol 2016, 7:1367 Lokmer et al. disturbed oyster microbiota by antibiotics and used a transplantation experiment to show that the interaction of an established microbiome can lead to increased mortality in transplanted animals. Vibrio colonization of solid tissues was also more frequent in transplanted animals further suggesting that change of microbiome composition by transplantation reduces the ability of oysters to maintain microbiome stability and prevent disease.

28* Pierce ML, Ward JE: Gut microbiomes of the eastern oyster (Crassostrea virginica) and the blue mussel (Mytilus edulis): temporal variation and the influence of marine aggregate associated microbial communities. mSphere 2019, 4:e00730- 19 http://dx.doi.org/10.1128/mSphere.00730-19 The microbial communities of the aggregates influence the composition of the gut core microbiota of these two bivalves, even though the composition of the core microbiota is very different from that of the aggregates. The gut core microbiota of Crassostrea virginica and Mytilus edulis show strong similarities, linked potentially to their common suspension feeding mode.

29. Trabal N, Mazon-Suàstegui JM, Vàzquez-Juàrez R, Ascencio Valle $F$, Morales-Bojorquez $E$, Romero J: Molecular analysis of bacterial microbiota associated with oysters (Crassostrea gigas and Crassostrea corteziensis) in different growth phases at two cultivation sites. Microb Ecol 2012, 64:555569.

30 Pimentel ZT, Dufault-Thompson K, Russo KT, Scro AK, Smolowitz RM, Gomez-Chiarri M, Zhang Y: Microbiome analysis reveals diversity and function of Mollicutes associated with the eastern oyster, Crassostrea virginica. mSphere 2021, 6: e00227-21 http://dx.doi.org/10.1128/mSphere.00227-21.

31 Trabal Fernàndez $\mathrm{N}$, Mazon-Suàstegui JM, Vàzquez-Jàrez $\mathrm{R}$, Ascencio-Valle $\mathrm{F}$, Romero J: Changes in the composition and diversity of the bacterial microbiota associated with oysters (Crassostrea corteziensis, Crassostrea gigas and Crassostrea sikamea) during commercial production. FEMS Microbiol Ecol 2014, 88:69-83 http://dx.doi.org/10.1111/1574-6941.12270. 
32 King WL, Siboni N, Kahlke T, Dove M, O'Connor W, Mahbub KR, Jenkins C, Seymour JR, Labbate M: Regional and oyster microenvironmental scale heterogeneity in the Pacific oyster bacterial community. FEMS Microbiol Lett 2020, 96:fiaa054 http://dx.doi.org/10.1093/femsec/fiaa054.

33 Musella M, Wathsala R, Tavella T, Rampelli S, Barone M, Palladino G, Biagi E, Brigidi P, Turroni $\mathrm{S}$, Franzellitti S, Candela $\mathrm{M}$ : Tissue-scale microbiota of the Mediterranean mussel (Mytilus galloprovincialis) and its relationship with the environment. Sci Total Environ 2020, 717:137209 http://dx.doi.org/10.1016/j. scitotenv.2020.137209.

34* Pathirana $E$, Fuhrmann $M$, Whittington $R$, Hick $P$ : Influence of environment on the pathogenesis of Ostreid herpesvirus-1 (OsHV-1) infections in Pacific oysters (Crassostrea gigas) through differential microbiome responses. Heliyon 2019, 5: e02101 http://dx.doi.org/10.1016/j.heliyon.2019.e02101 Pacific oysters sourced from a single hatchery but raised in the field in 3 different places of Australia were challenged with OsHV-1. The initial microbiome composition was different in the three batches. Results showed that the different microbiomes of oysters responded differently with a differential outcome of OsHV-1 challenge.

35. Auguste M, Lasa A, Pallavicini A, Gualdi S, Vezzulli L, Canesi L: Exposure to TiO 2 nanoparticles induces shifts in the microbiota composition of Mytilus galloprovincialis hemolymph. Sci Total Environ 2019, 670:129-137.

36 Auguste M, Lasa A, Balbi T, Pallavicini A, Vezzulli L, Canesi L: Impact of nanoplastics on hemolymph immune parameters and microbiota composition in Mytilus galloprovincialis. Mar Environ Res 2020, 159.

37 Britt A, Bernini M, McSweeney B, Dalapati S, Duchin S, Cavanna K, Santos N, Donovan G, O'Byrne K, Noyes $S$ et al.: The effects of atrazine on the microbiome of the eastern oyster: Crassostrea virginica. Sci Rep 2020, 10.

38 Balbi T, Vezzulli L, Lasa A, Pallavicini A, Canesi L: Insight into the microbial communities associated with first larval stages of Mytilus galloprovincialis: possible interference by estrogenic compounds. Comp Biochem Physiol C Toxicol 2020, 237.

39 Scanes E, Parker LM, Seymour JR, Siboni N, King WL, Danckert NP, Wegner KM, Dove MC, O'Connor WA, Ross PM: Climate change alters the haemolymph microbiome of oysters. Mar Pollut Bull 2021, 164:111991 http://dx.doi.org/ 10.1016/j.marpolbul.2021.111991.

40. de Lorgeril J, Escoubas JM, Loubiere V, Pernet P, Le Gall P, Vergnes A, Aujoulat F, Jeannot JL, Jumas-Bilak $E$, Got $P$ et al.: Inefficient immune response is associated with microbial permissiveness in juvenile oysters affected by mass mortalities on field. Fish Shellfish Immunol 2018, 77:156-163 http://dx.doi.org/10.1016/j.fsi.2018.03.027.

41 Destoumieux-Garzon D, Canesi L, Oyanedel D, Travers M-A, Charrière GM, Pruzzo C, Vezzulli L: Vibrio-bivalve interactions in health and disease. Environ Microbiol 2020, 22:4323-4341.

42 Green TJ, Barnes AC: Bacterial diversity of the digestive gland of Sydney rock oysters, Saccostrea glomerata infected with the paramyxean parasite, Marteilia sydneyi. J Appl Microbiol 2010, 109:613-622.

43 de Lorgeril J, Lucasson A, Petton B, Toulza E, Montagnani C, Clerissi C, Vidal-Dupiol J, Chaparro C, Galinier R, Escoubas J-M et al.: Immune-suppression by OsHV-1 viral infection causes fatal bacteraemia in Pacific oysters. Nat Commun 2018, 9:4215 http://dx.doi.org/10.1038/s41467-01806659-3.

44 King WL, Jenkins C, Go J, Siboni N, Seymour JR, Labbate M: Characterisation of the Pacific oyster microbiome during a summer mortality event. Microb Ecol 2019, 77:502-512.

45 Stevick RJ, Sohn S, Modak TH, Nelson DR, Rowley DC, Tammi K, Smolowitz R, Markey Lundgren $\mathrm{K}$, Post AF, Gomez-Chiarri M: Bacterial community dynamics in an oyster hatchery in response to probiotic treatment. Front Microbiol 2019, 10:1060 http://dx.doi.org/10.3389/fmicb.2019.01060. 
46 Richard M, Rolland JL, Gueguen Y, de Lorgeril J, Pouzadoux J, Mostajir B, Bec B, Mas S, Parin D, Le Gall P, Mortreux S et al.: In situ characterisation of pathogen dynamics during a Pacific oyster mortality syndrome episode. Mar Environ Res 2021, 165: 105251 http://dx.doi.org/10.1016/j.marenvres.2020.105251.

47 Bass D, Stentiford GD, Wang H-C, Koskella B, Tyler CR: The pathobiome in animal and plant diseases. Trends Ecol Evol 2019, 34:996-1008 http://dx.doi.org/10.1016/j.tree.2019.07.012.

48 King WL, Siboni N, Williams NLR, Kahlke T, Nguyen KV, Jenkins C, Dove M, O'Connor W, Seymour JR, Labbate M: Variability in the composition of pacific oyster microbiomes across oyster families exhibiting different levels of susceptibility to OsHV-1 mvar disease. Front Microbiol 2019, 10: 473 http://dx.doi.org/ 10.3389/fmicb.2019.00473.

49* Clerissi C, de Lorgeril J, Petton B, Lucasson A, Escoubas J-M, Gueguen Y, Dégremont L, Mitta G, Toulza E: Microbiota composition and evenness predict survival rate of oysters confronted to pacific oyster mortality syndrome. Front Microbiol 2020, 11:311 http://dx.doi.org/10.3389/ fmicb.2020.00311 Clerissi et al. placed oysters from resistant and susceptible families in field condition for 5 days during a Pacific Oyster Mortality Syndrome outbreak. All oysters from susceptible families died and all oysters from the resistant family survived. The analyses of oyster microbiota at the early steps of infection revealed differences between resistant and susceptible oyster families. These differences suggested that both the structure and the composition might predict oyster mortalities. In particular, they found that three bacterial families were significantly associated with resistant oysters: Colwelliaceae, Cyanobacteria (Subsection III, family 1), and Rhodobacteraceae.

50 Ward GM, Feist SW, Noguera P, Marcos-Lopez M, Ross S, Green M, Urrutia A, Bass D: Detection and characterisation of haplosporidian parasites of the blue mussel Mytilus edulis, including description of the novel parasite Minchinia mytili n. sp. Dis Aquat Organ 2019, 133:57-68.

51 Lynch SA, Lepée-Rivero S, Kelly R, Quinn E, Coghlan A, Bookelaar B, Morgan E, Finarelli JA, Carlsson J, Culloty SC: Detection of haplosporidian protistan parasites supports an increase to their known diversity, geographic range and bivalve host specificity. Parasitology 2020, 147:584- 592.

52 Rajeev R, Adithya KK, Kiran GS, Selvin J: Healthy microbiome : a key to successful and sustainable shrimp aquaculture. Rev Aquac 2021, 13:238-258.

53 Knipe H, Temperton B, Lange A, Bass D, Tyler CR: Probiotics and competitive exclusion of pathogens in shrimp aquaculture. Rev Aquacult 2021, 13:324-452.

54 Pita L, Rix L, Slaby BM et al.: The sponge holobiont in a changing ocean: from microbentitle>. Microbiome 2018, 6:46 http://dx. doi.org/10.1186/s40168-018-0428-1.

55 Timmins-Schiffman E, White SJ, Thompson RE et al.: Coupled microbiome analyses highlights relative functional roles of bacteria in a bivalve hatchery. Environ Microbiome 2021, 16:7 http://dx.doi.org/10.1186/s40793-021-00376-z 
Figure 1

Articles published since 2006 reporting the microbial community in bivalve molluscs. Source Scopus May 2021, Query: 16S AND bivalve AND (microbiota OR microbiome OR community OR metabarcoding), output has been checked, removing non-relevant articles.

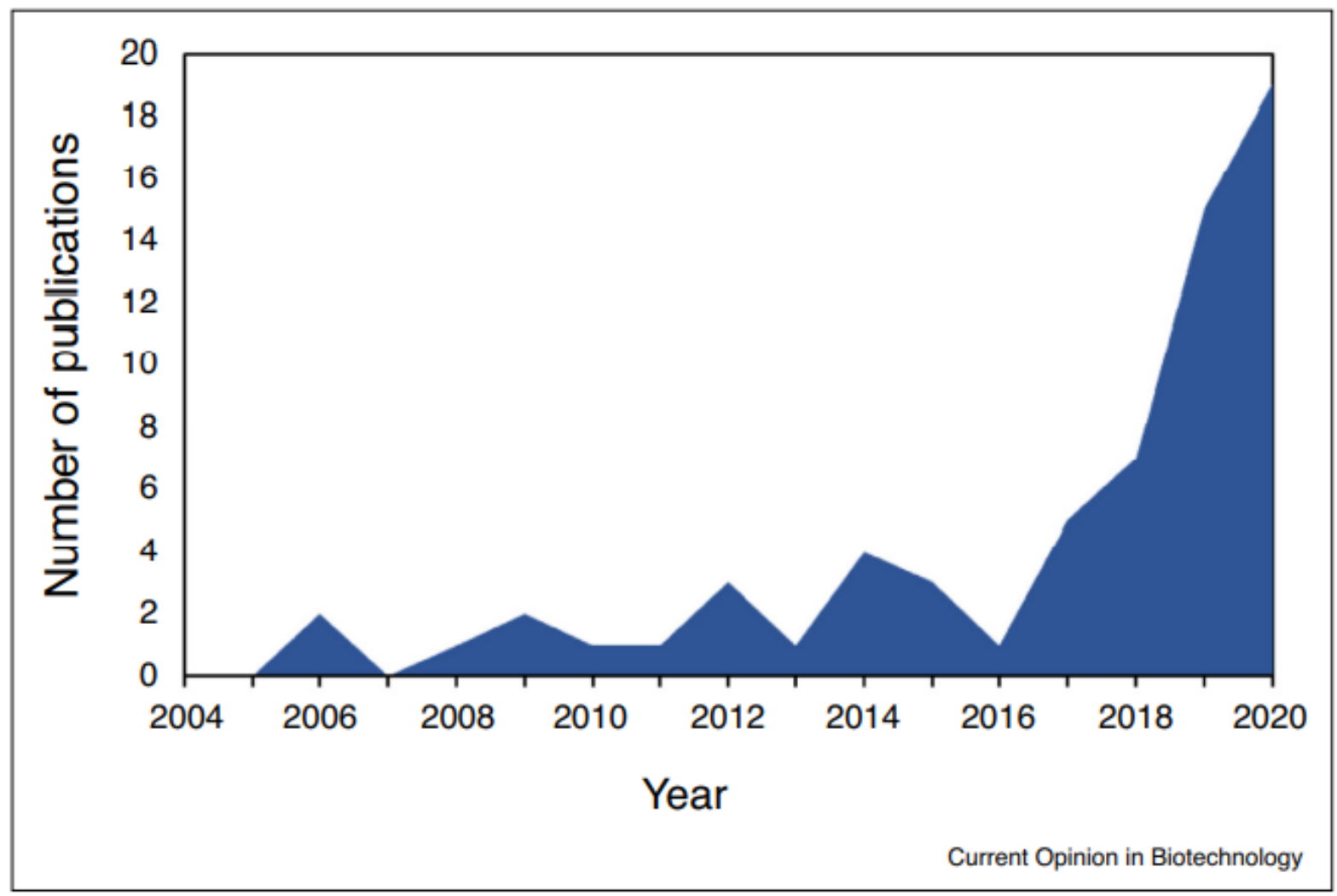




\section{Figure 2}

Host and environmental factors acting on bivalve microbiota. Some of these factors, alone or in combination, have been shown to lead to dysbiosis, diseases and recovery.

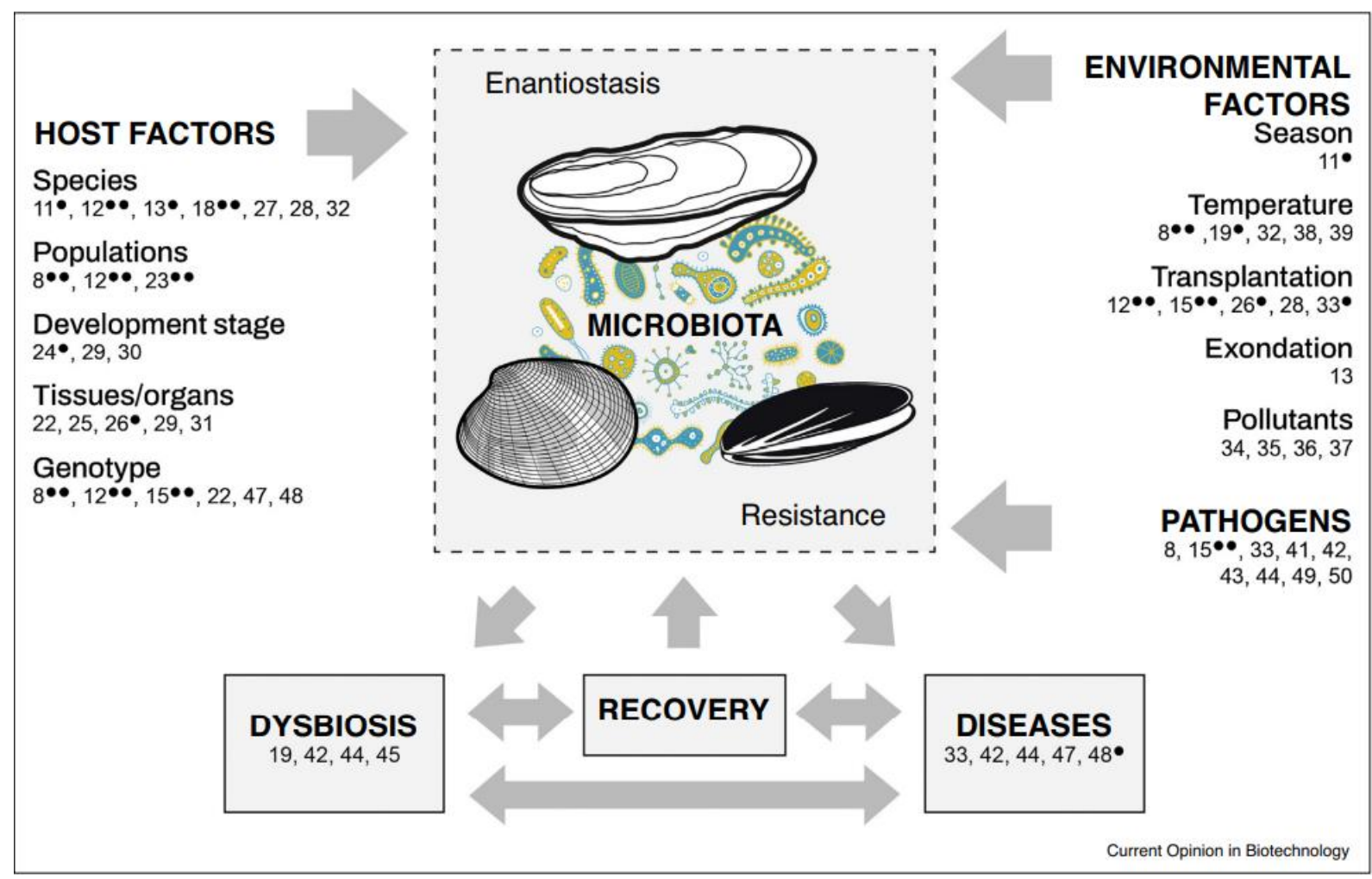


Table 1

Bacterial microbiota taxa associated with a better resistance of Crassostrea gigas oyster during disease outbreaks or experimental challenge.

\begin{tabular}{lllll}
\hline Bacteria taxa (family or genus level) & life stage & Disease & Mortality outbreak \\
\hline Cyanobacteria (Subsection III, family I) & juveniles & Ostreid herpesvirus Disease & Field outbreak & References \\
Rhodobacteraceae & juveniles & Ostreid herpesvirus Disease & Field outbreak & {$\left[48^{*}\right]$} \\
Colwelliaceae & juveniles & Ostreid herpesvirus Disease & Field outbreak & {$\left[48^{*}\right]$} \\
Oceanospirillales & larvae & Vibriosis & Experimental challenge & {$\left[48^{*}\right]$} \\
Winogradskyella & juveniles & Ostreid herpesvirus Disease & Field outbreak & Field outbreak \\
Bradyrhizobiaceae & juveniles & Ostreid herpesvirus Disease & [47] & {$[47]$} \\
\hline
\end{tabular}

